\title{
PRAŽSKÁ UNIVERZITA ZA VLÁDY FERDINANDA I. - JEJÍ VZTAH K PANOVNÍKOVI A K PRAŽSKÝM MĚSTŮM
}

\author{
MAREK ĎURČANSKÝ
}

\section{PRAGUE UNIVERSITY DURING THE RULE OF FERDINAND I: ITS RELATION TO THE EMPEROR AND THE TOWNS OF PRAGUE}

This contribution follows the relation of the Prague Utraquist university to the towns of Prague and, in parallel, its relation to Ferdinand I (1526-1564), Holy Roman Emperor and ruler of the Czech Lands. In the power struggle between the nobles and the burghers, the university tended to side with the towns, especially with Prague. The policy of Ferdinand I was, however, openly anti-burgher, anti-town. Within this political environment, university's good relations with the towns and cities were therefore of a diminishing importance, although in the university's daily operations, they remained essential since most of its students were burghers. Prague university's relations with Ferdinand I were cautious, but not openly hostile. Its relations to the towns of Prague is traced not only on the level of political connections but also in terms of their daily coexistence, which included e.g. conflicts between the justice systems of the university and the towns, repairs to university buildings, or issues pertaining to ecclesiastic administration. Despite various efforts of Utraquist estates, proposed university reforms either did not take place or were merely partial.

Keywords: Prague university - Ferdinand I - Prague - uprising of the estates - 16th century

DOI: $10.14712 / 23365730.2019 .9$

Nejstarší středoevropské vysoké učení ztratilo po husitských válkách hodně ze svého někdejšího lesku. ${ }^{1}$ Přesto ale v době nástupu Ferdinanda I. na český trůn stále představovalo významné duchovní ohnisko alespoň v rámci země, mezi jejímž obyvatelstvem převažovali přívrženci utrakvismu. Důležitou roli ve vývoji pražské univerzity hrála ve sledované době vazba na česká města, především na pražské souměstí. Praha představovala pro vysoké učení hlavní mocenskou oporu se všemi pozitivy a negativy, jež takové spojení s sebou přinášelo. Jestliže v době Ferdinandovy české korunovace stála spojená Praha pod vedením Jana Paška z Vratu na vrcholu svého mocenského vzestupu, v době královy smrti už byla česká královská města v důsledku nezdařeného odboje roku 1547 jen marginální politickou silou, jejíž klesající význam vyvažovaly hlavně výsledky na poli hospodářském a kulturním.

1 Tato studie vznikla jako výstup z projektu Praha - residence Ferdinanda I. Habsburského a jeho kulturního okruhu, 1526-1564, podpořeného Grantovou agenturou České republiky (grant č. 13-16963S, řešitel Jaroslava Hausenblasová) 
Předkládaný příspěvek tvoří doplněk nedávno vydané studie zaměřené na vazby pražské univerzity k českým městům za panování Ferdinanda $\mathrm{I}^{2}{ }^{2}$ Cílem tohoto textu je pokusit se v hlavních obrysech paralelně sledovat vztah pražské univerzity ke králi a hlavnímu městu země v prvních desetiletích poté, co Jagellonce na českém trůně nahradili Habsburkové. Úkol je to snad o to smysluplnější, že zatím nemáme podrobnější zpracování jejích dějin za vlády Ferdinanda I. Předcházející jagellonské období, ${ }^{3}$ podobně jako poslední zhruba půlstoletí existence utrakvistické univerzity, ${ }^{4}$ se těšily mnohem intenzivnější pozornosti historiků české vysokoškolské vzdělanosti, což lze zejména ve druhém případě snadno vysvětlit také neporovnatelně větším množstvím dochovaných pramenů, jež máme k dispozici. Pro dobu Ferdinanda I. lze nalézt jen málo dosud nepoužitých písemností, spíše je třeba o něco více kombinovat prameny dosud vzájemně nekonfrontované a snažit se je reinterpretovat. ${ }^{5}$ Kariéra mladšího z vnuků Maxmiliána I. na českém trůnu se ostatně (a podle mého soudu právem) těší jistým, poměrně úspěšným snahám o rehabilitaci. ${ }^{6}$ At’ tak či onak, role pražské univerzity byla při všem útlumu dostatečně významná na to, aby se jí zabývaly zemské

2 Marek ĎurČAnSKÝ, Pražská utrakvistická univerzita a česká města za vlády Ferdinanda I., Kuděj. Časopis pro kulturní dějiny 19/2, 2018, s. 157-176. Zde je také podrobně uvedena relevantní literatura, proto níže uvádím jen literaturu vztahující se př́mo k tématu této stati, a nikoli k dějinám pražské univerzity ze všech možných úhlů pohledu.

3 Jiří PEŠEK, Některé otázky dějin univerzity pražské jagellonského obdobi (1471-1526), Acta Universitatis Carolinae Pragensis - Historia Universitatis Carolinae Pragensis (dále AUC-HUCP), 18/1, 1978, s. $129-171$.

4 Zikmund WINTER, O životě na vysokých školách pražských knihy dvoje. Kulturni obraz XV. a XVI. století, Praha 1899. Wintrova díla týkající se univerzity jsou o to významnější, že jejich autor mohl ještě užít pramenů z Archivu města Prahy a Archivu Univerzity Karlovy, které od roku 1945 již nemáme k dispozici. Winter hojně cituje nejstarší děkanskou knihu filozofické fakulty (tzv. Liber decanorum facultatis philosophicae ab a. 1367 usque ad a. 1585, původní signatura M 17). Je ovšem k dispozici její letitá edice, kterou bylo možné pro potřeby této stati rovněž využít. Srov. Monumenta historica Universitatis Carolo-Ferdinandeae Pragensis, tomus I, pars 2, Liber decanorum facultatis philosophicae ab a. 1367 usque ad a. 1585, Pragae 1832 (dále jen MUP I/2). Vedle děkanské knihy byla nedávno nově editována také tzv. Acta rectorum: František ŠMAHEL - Gabriel Silagi (edd.), Statuta et acta rectorum Universitatis Carolinae Pragensis 1360-1614 (Documenta historica Universitatis Carolinae Pragensis I), Praha 2018, s. 53-185.

5 Práci s prameny moc neulehčuje existence tří moderních syntetických zpracování, která bohužel neobsahují poznámkový aparát, pouze seznamy literatury (příp. stručnou obecnou informaci o nejdůležitějších pramenech). Srov. František Kavka a kol., Stručné dějiny University Karlovy, Praha 1964 (autory př́slušných pasáží jsou František Šmahel a Miroslav Truc; dále jen Stručné dějiny University Karlovy); Josef PeTrÁŇ, Nástin dějin filosofické fakulty Univerzity Karlovy v Praze (do roku 1948), Praha 1983; Michal Svatoš (ed.), Dějiny Univerzity Karlovy, I, 1347/48-1622, Praha 1995 (autory př́íslušných pasáží jsou Michal Svatoš, Jiří Pešek a Ivana Čornejová; dále jen Dějiny Univerzity Karlovy, I). Radu aspektů vztahu mezi univerzitou a Ferdinandem I. tematizuje Jaroslava Hausenblasová, Ferdinand I. a pražský humanistický okruh. Několik poznámek k problematice panovnického mecenátu kolem poloviny 16. století, AUC-HUCP 47/1-2, 2007, s. 89-97, resp. TÁž, Intelektuálové na cestách. Kulturní okruh Ferdinanda I. mezi Vidni a Prahou v první polovině 16. století, Documenta Pragensia 27, 2008, s. 451-466, zvl. s. 464n. Nejnovější monografií k dějinám předbělohorské univerzity je Mlada Holá, Studentské koleje pražské univerzity v pozdním středověku a raném novověku. Déjiny - správa - úřední písemnosti (do roku 1622), Praha 2018.

6 Výrazně např. Jiř́ PEŠEK, Ferdinand I., in: Marie Ryantová - Petr Vorel (eds.), Čeští králové, Praha - Litomyšl 2008, s. 303-319, podobně ve vztahu k Praze Jaroslava Hausenblasová, Prag in der Regierungszeit Ferdinands I. Die Stellung der Stadt im System des höfischen Residenznetwerks, Historie - otázky - problémy 7/2, 2015, s. 9-28. Vedle samotné osobnosti Ferdinanda I. a jeho politiky je pozitivněji hodnocena rovněž užší integrace českých zemí do středoevropského prostoru a Prahy do rezidenční sítě habsburských panovníků. Je zjevné, že Ferdinand I. položil dostatečné základy pro pozdější kulturní a intelektuální rozvoj Prahy v době rudolfinské, z nějž čerpala také pražská univerzita. K vývoji vztahu české historiografie k Ferdinandovi I. srov. přehledný esej Karla Pacovského v knize Alfreda KoHlera, Ferdinand I. (1503-1564). Kníže, král a císař, České Budějovice 2017, s. 259-283. 
úřady, panovník i samosprávné korporace pražského souměstí. Samozřejmě ne vždy se stejnou intenzitou.

Nejisté postavení vysokého učení v mocenském poli mezi schopným panovníkem a jednou z dosavadních hlavních politických sil v zemi, již pražská města bezesporu představovala, bylo v době konfesijních turbulencí zároveň příležitostí pro změny. Nahlížíme-li na problematiku v širším středoevropském kontextu, pak Ferdinand ve vztahu k vídeňské univerzitě rozhodně prokázal, že si je vědom významu vysokého školství a začátky jeho reformních snah na tomto poli šly ve Vídni ruku v ruce se změnami v oblasti městské správy. ${ }^{7}$ Otázka, nakolik se Ferdinand I. reformou vídeňské univerzity inspiroval ve svých pražských plánech, nebyla zatím podrobněji tematizována. ${ }^{8}$

V posledních letech panování Jagellonců byla univerzita do značné míry paralyzována mocenským zápasem mezi šlechtou a městským stavem, zároveň ale také konfesijními rozpory, a to zejména v pražském souměstí, které bylo i po formální stránce sjednoceno. Ačkoli se menší část mistrů klonila k reformaci, přímé zásahy luteránsky orientované staroměstské rady do univerzitních záležitostí vrcholící obsazením místa kazatele v Betlémské kapli radikálem Martinem Hánkem a vnucenou změnou na postu děkana filozofické fakulty posunuly dosavadní narušování univerzitní autonomie o notný kus. Stalo se tak krátce před dočasným spojením Starého a Nového Města (1523-1528), jehož symbolem bylo také ustavení společné městské rady. Záhy ji obsadili starokališnicky orientovaní př́ívrženci M. Jana Paška z Vratu. Ani oni se nevyhýbali zásahům do vnitřních záležitostí univerzity, v jejímž čele stanul v roce 1527 někdejší administrátor konsistoře podobojí M. Havel Cahera. Rozdělení sjednocené Prahy a Paškův pád v roce 1528 byl také jeho koncem - brojení proti Ferdinandovi I. Caherovi přineslo nejprve odvolání, a poté vyhnanství, z něhož se již neměl vrátit. V periodizaci náboženské orientace utrakvistické univerzity, kterou navrhl Jiří Pešek, končí rokem 1528 fáze bojů o prosazení luterství a nastává období intenzivní orientace na univerzitu ve Wittenbergu. ${ }^{9}$ To vztahy k Ferdinandovi I., který již v roce 1524 studium zde svým poddaným zakázal, ${ }^{10}$ jistě př́liš nevylepšilo. Každopádně zde studovala řada profilujících osobností pražského učení následujících desetiletí (Matouš Collinus z Chotěřiny, Jan Šentygar z Chotěřiny, Šebestián Aerichalcus aj.). Tento trend podpořila také generační výměna v důsledku úmrtí několika starších mistrů ortodoxní utrakvistické orientace během morových epidemií. ${ }^{11}$

Rady pražských měst přitom zůstávaly - přes všechny konfesionální neshody - po dobu panování Ferdinanda I. nekatolické. Odpovídalo to ostatně znění privilegia císaře Zikmunda Lucemburského z roku 1435. Po roce 1547 Ferdinand I. toto privilegium nepotvrdil a připravil tak půdu pro pozdější dobu: od roku 1571, kdy ve staroměstské radě zasedl

7 A. KoHLeR, Ferdinand I., s. 62n. K reformě vídeňské univerzity uskutečněné Ferdinandem I. srov. Kurt MüHLBERGER, Ferdinand I. als Neugestalter der Universität Wien. ,, [...] das Generalstudium, gleichsam eine hervorragende Pflanzstätte zur Verbreitung der Religion und zur richtigen Führung des Staates [...]“, in: Wilfried Seipel (Hg.), Kaiser Ferdinand I. 1503-1564. Das Werden der Habsburgermonarchie, Wien 2003, s. 265-275, a TY̌ž, Kaiser Maximilian II. und die Universität Wien, in: Friedrich Edelmeyer - Alfred Kohler (Hgg.), Kaiser Maximilian II.: Kultur und Politik im 16. Jahrhundert, Wien - München 1992, s. 203-230 (zejména úvodní pasáže).

8 Základní otázky a literaturu shrnuje zdařile J. HausEnBLAsová, Intelektuálové na cestách, s. 461-463.

9 Jiří PEŠEK, Pražská utrakvistická univerzita a náboženské poměry 16. století, AUC-HUCP 36-38/1-2, 19961998, s. 31-40.

10 A. KoHLER, Ferdinand I., s. 148.

11 Stručné dějiny University Karlovy, s. 83 
plzeňský rodák Šebestián Agricola z Horšova, počet katolických exponentů v následujících desetiletích postupně vzrůstal, neúměrně k zastoupení katolíků mezi staroměstskými měšt’any. ${ }^{12}$ Ani jedno z toho nebylo nekatolickými předáky pražských měst zapomenuto - Zikmundovo privilegium i př́ichod prvního katolíka do staroměstské rady výrazně reflektuje tzv. Větší Apologie stavů českých z roku 1618.13

Ani nekatolická konfesijní orientace ovšem neuchránila univerzitu dalšího vměšování představitelů pražské správy do vnitrouniverzitních záležitostí. Problematické byly tradičně otázky překrývání se akademické a městské jurisdikce. Př́ípad z masopustního období roku 1534 byl děkanem M. Jindřichem Curiem označen jako „ausum Pragensium contra privilegia“. Staroměstská rada tehdy nechala na tři dny uvěznit studenta, který hrál hlavní roli v Plautově komedii Chvástavý vojín. Studenti hru provozovali na novoměstské radnici, což vzbudilo nelibost Staroměstských a uvěznění uvedeného studenta odůvodnili absurdním tvrzením, že došlo k porušení panovníkem vydaného zákazu shromažd’ování lidu. Děkan zápis uzavřel ironickou poznámkou: „... ab illis fieri debeat, qui se patronos studii [jactant]". ${ }^{14}$

$Z$ významnějších rozporů mezi akademickou a městskou jurisdikcí ve sledované době je třeba připomenout ještě signifikantní př́ípad z roku 1542. Tehdy z popudu staroměstského kancléře M. Martina Kuthena ohledali zástupci městské rady majetek, který po sobě bez posledního pořízení zanechal v univerzitní vsi Michle jeden z bohatších venkovanů. Nastalý spor vyhrotilo zatčení M. Zikmunda Antocha z Helfenburka Staroměstskými, takže univerzita nakonec hledala zastání u komorního soudu. Tento případ i drobnější rozpory postupně vedly $\mathrm{k}$ hledání bližších vazeb mezi univerzitou a Novým Městem pražským. ${ }^{15}$

$\mathrm{K}$ rozporům $\mathrm{v}$ otázce jurisdikce docházelo také mezi univerzitou a s ní personálně značně provázanou utrakvistickou konsistoří, prričemž do projednávaných př́ípadů mohla zasahovat rovněž obec, př́padně farnost. Na jaře 1536 obžalovala univerzita faráře Týnského kostela Vojtěcha, který její představitele pohaněl poté, co uvěznili rektora školy u uvedeného kostela Šimůnka. Farář předvolaný před konsistoř uváděl, že před administrátora předstoupil pouze kvůli němu, ,a ne k vůli pánům mistrům“. A dodával: ,kolikrát by mne koli obeslali oni, jim $k$ vůli nestanu a odpovídati nechci, a pane administrátor, račte sobě o to dobrý pokoj učiniti; neb to jest věc i pánů Pražanů i pánů osadnich". Představitelům univerzity obžalovaný navíc vyčítal, že „toho masojídka to kniže vítali, což jsou králi pánu svému neučinili a Páni Pražané také něco k pánům mistrům promluvili“ ${ }^{16}$ Jen o měsíc později byl ze strany univerzity obviněn farář u kostela sv. Havla Pavel, který jim měl vyhrožovat během kázání a zesměšňovat je, ,a to slovy lehkomyslnými pravě: ti učenci v učení Pražském že se sklátili $u$ víre a nevédí, jak věři". Farár̆ tuto část obvinění popřel, měl prý pouze říci, že „mnozi učeni lidé nyni jsou se zpletli a nevědí, jak věřr “. Sám se přihlásil k tomu, ,jak jsou staři mistři vyznali, jako mistr Matěj Pařizkej“ (tedy M. Matěj z Janova). Mistři se poté dali

12 Na základě prosopografie, kterou zpracoval Jaroslav DoušA, Seznamy staroměstských konšeli̊ z let 1547-1650, Pražský sborník historický 14, 1981, s. 65-119.

13 Vácslav Šubrt (ed.), Apologie druhá staviov Království českého, Praha 1862, s. 72-76.

14 MUP I/2, s. 315n; Z. WinTER, O životě, s. 437.

15 Stručné déjiny University Karlovy, s. 84.

16 Klement Borový (ed.), Jednání a dopisy konsistoře katolické i utrakvistické, I, Akta konsistoře utrakvistické, Praha 1868, s. 112-113. O rok později (v dubnu 1537) obvinili představitelé univerzity týnského faráře Vojtěcha znovu. Tentokrát měl prímo v kostele zbít kantora, což bylo vnímáno rovněž jako potupa rektora univerzity. Tamtéž, s. 119n. 
přesvědčit „,na snažné žádosti naše [tj. konsistoriánů] i pánův Pražanův to jsou v moc dali, aby ubrmanským během výpovéd' učiněna byla“. ${ }^{17}$

Jedním z výrazných průsečíků mezi univerzitou, pražskými městy a zemskými úrúady, resp. panovníkem, bylo ustavení a další osudy místa lektora řeckého jazyka. Shodou okolností bylo nakonec vázáno pouze na jedinou, ale výraznou osobnost mezi soudobými humanisty $-\mathrm{M}$. Matouše Collina $\mathrm{z}$ Chotěřiny. Lektorát měl být finančně zajištěn z nadace staroměstského měšt’ana, právníka Jana France z Královské Hory, který v roce 1537 na jeho zř́zení věnoval 1000 kop grošů českých. Nadaci poté spravovala staroměstská rada. Když místo odmítl významný spolupracovník Erasma Rotterdamského Řehoř Hrubý z Jelení, stal se vážným kandidátem Matouš Collinus, který přišel do Prahy z Wittenbergu na podzim 1540 vybaven dvěma doporučujícími listy Filipa Melanchtona adresovanými - symptomaticky - univerzitě a staroměstské městské radě. ${ }^{18}$ Zdlouhavá jednání mezi oběma institucemi nakonec v létě 1541 urychlil zákrok samotného Ferdinanda I. Nebylo to naposledy, kdy panovník osobně zasáhl do Collinových osudů. Univerzitní lektor řeckého jazyka placený z nadace spravované městem byl i nadále v komplikovaném postavení, v konfliktu dvou loajalit, násobeném ještě opakovanými osočováními z luterství vedenými ze staroutrakvistických pozic. Vyrovnat se s tak složitou situací pomáhaly Collinovi jeho vazby na dvůr Ferdinanda I., zprostředkované zejména díky učencovu přátelství s Janem Hodějovským. ${ }^{19}$

Po celé 16. století visela nad univerzitou otázka reformy, jejíž aktuální podoba se proměňovala podle náboženské a politické situace. Některé otázky, zejména ekonomické, se ale objevovaly opakovaně. Problematika univerzity tak přicházela na pořad jednání zemských sněmů a návrhy byly předkládány rovněž panovníkovi. Revize univerzitních statut, $\mathrm{k}$ níž došlo $\mathrm{v}$ roce 1528 , představovala především přehledné ,shrnutí a uspořádáni dřive již platných norem “ ${ }^{20}$ Prostřednictvím doplňků, a především vypuštěním neaktuálních pasáží měla být starší pravidla uvedena do souladu s realitou počátku 16. století.

Jedním z témat, která byla tehdy ve vztahu k univerzitě trvale aktuální, byl dostatek nadaných studentů za situace, kdy studiu svých poddaných některé vrchnosti bránily. Protože bylo na dostatku studentů závislé také personální zajištění utrakvistické farní sítě, šlechtické stavy univerzitě na sněmu v roce 1531 vyhověly, předpokladem měl být ale závazek dotyčného dát se na dráhu duchovního nebo univerzitního mistra. ${ }^{21}$ Směřování k radikálnější reformě pražské univerzity bylo do značné míry souběžné se situací ve Vídni, která rovněž trpěla nedostatkem studentů (propad souvisel s reformací i s trvajícím tureckým ohrožením). ${ }^{22}$ Snahy

17 Tamtéž, s. 113n. O případech obou kněží také F. ŠMAHEL - G. SilaGi (edd.), Statuta et acta, s. 89n.

18 Opis výsledné smlouvy mezi staroměstskou radou a univerzitou viz Archiv Univerzity Karlovy (dále jen AUK), fond Rukopisy A, sign. A 17 II-1, p. 234-248; srov. také F. ŠMAHel - G. SilAGi (edd.), Statuta et acta, s. 9599. Ve vztahu k Melanchtonovi je možné ještě zmínit jeho předchozí dopis z roku 1538, jímž žádal o vypůjčení rukopisu obsahujícího Př́rodopis Plinia staršího a listy Plinia mladšího. Rukopis kdysi univerzitě věnovala staroměstská rada, čímž děkan vysvětloval, že se na Staroměstské radní obracel o svolení, aby mohl vzácné dílo Melanchtonovi na rok zapůjčit. MUP I/2, s. 321; Z. WINTER, O životě, s. 376, 381.

19 Srov. zejména podrobný biogram s přehledem díla a vyčerpávajícím výčtem starší literatury a pramenů v nedocenitelné př́ručce Josefa HeJNICE - Jana MARTínKA, Rukovět humanistického básnictví v Čechách a na Moravě, I, Praha 1966, s. 416-451. Z novější literatury přehledně Dějiny Univerzity Karlovy, I, s. 215n, $233 \mathrm{n}$.

20 Stručné déjiny University Karlovy, s. 82n.

21 Sněmy české I, Praha 1874, svolení stavů podobojí 11. 6. 1531; AUK, fond Rukopisy A, sign. A 17 I-1, p. 116.

22 Albert MüLler, Universitätsbesuch und Städtische Herkunft. Forschungsprobleme am Beispiel österreichischer Städte und der Wiener Universität 1347-1554, in: Kurt Mühlber - Thomas Maisel (eds.), Aspekte der Bildungs- und Universitätsgeschichte. 16.-19. Jahrhundert, Wien 1993, s. 332-360. 
o proměnu vídeňské univerzity $\mathrm{v}$ zeměpanskou instituci, která by se výměnou za finanční zajištění podř́́dila zájmům a potřebám panovníka, narážely zprvu na neochotu vysokého učení, jehož mistři se snažili hlavně o potvrzení stávajících privilegií. Řada reformních kroků nakonec vyústila v tzv. reformatio nova, jež přizpůsobila dosavadní strukturu novým poměrům. $\mathrm{V}$ porovnání s Vídní v Praze $\mathrm{k}$ radikálnější reformě univerzity nedošlo. Ve srovnání s palčivými finančními a politickými otázkami projednávanými na zemských sněmech se přece jenom jednalo o otázku méně závažnou, která několikrát vyzněla do ztracena.

Nakonec král ve stejném roce, kdy bylo vydáno jedno z reformních opatření pro vídeňskou univerzitu, potvrdil privilegia pražskému vysokému učení (5. května 1537). ${ }^{23}$ Podle V. V. Tomka bylo potvrzení privilegií jistou náplastí na to, že se sněm toho roku vůbec nezabýval návrhy na reformu univerzity, které předložili předáci stavů podobojí Jan IV. z Pernštejna a Václav (?) z Vartenberka. ${ }^{24}$ Opravdu vážně míněná iniciativa k reformě univerzity se objevila teprve na programu jednání sněmu z roku 1545 , kdy byla ustavena pětičlenná komise (po jedné osobě z každého stavu a administrátoři obou konsistoří), ale práce nebyla dovedena včas ke konci. ${ }^{25}$ Jsme dnes ovšem velmi vděčni za svého druhu „vedlejší produkt“", který vznikl pravděpodobně tehdy, v souvislosti s prípravami reformy, v podobě nejstaršího inventáře univerzitního archivu (1545). ${ }^{26}$

Významným mezníkem nejen pro vztah panovníka a stavů, ale především pro česká královská města a rovněž pro univerzitu byl nezdařený odboj roku 1547. Vysoké učení se přidalo, byt' nijak výrazně, $\mathrm{k}$ hlavnímu proudu nekatolických stavů odmítajících s odkazem na zemská práva podpořit Ferdinanda I. a Karla V. v boji proti saskému kurfiřtovi Janu Fridrichovi. Pro jednání nekatolických stavů poskytlo - ostatně jako již mnohokrát - zázemí v Karolinu. Jednalo se o následující momenty: 1) Společné jednání obcí Starého a Nového Města započaté 9. února v reakci na mandát Ferdinanda I. K nim se ve dnech 13.-16. února připojili také příslušníci vyšších stavů. Výsledkem bylo společné odmítnutí královského mandátů v tzv. „snešení a nařizení přátelském“.27 2) Jednání „o středopostí“ roku 1547, konkrétně v rozmezí 19.-23. března. Výsledný dokument (,přátelské snešeni stavio čes$\left.k y ́ c h{ }^{c *}\right)^{28}$ měl sloužit jako základ pro jednání na budoucím sněmu. ${ }^{29}$ Právě toto jednání bylo klíčové, což reflektují i prameny z opačného tábora. ${ }^{30} 3$ ) Další jednání nekatolických stavů od 18. dubna, jehož účastníci průběžně jednali se zemskými úředníky na Pražském hradě. Když do Prahy dorazila zpráva o bitvě u Mühlberka, shromáždila se v Karlově koleji část

23 AUK, fond Listiny I, sign. I/92, 5. 5. 1537, Praha. K nařízením vydaným v tom samém roce pro vídeňskou univerzitu srov. K. MüHLBERGER, Ferdinand I. als Neugestalter, s. 271.

24 Wenzel Wladiwoj Tомек, Geschichte der Prager Universität, Prag 1849, s. 155; F. ŠMahel - G. Silagi (edd.), Statuta et acta, s. 92.

25 W. W. Tомек, Geschichte der Prager Universität, s. 156n; Sněmy české I, s. 618, 625, 633; Sněmy české II, Praha 1880, s. 27.

26 Karel KuČERA - Miroslav Truc, Archiv University Karlovy. Průvodce po archivnich fondech, Praha 1961, s. 10n.

27 Karel Tieftrunk, Odpor stavův českých proti Ferdinandovi I., Praha 1872, s. 90-97.

28 Srov. Petr Vorel, „Prátelské snešeni stavưv českých “ $z$ brezna 1547 a jeho signatáři, in: týž (ed.), Stavovský odboj roku 1547. První krize habsburské monarchie. Sborník prŕspěvků z vědecké konference konané v Pardubicích 29.-30. 9. 1997, Pardubice - Praha 1999, s. 81-124.

29 K. TieftrunK, Odpor stavưv českých, s. 109-126.

30 „Avšak neohližejíc se na psaní a jistý spravedlivý rozkaz náš, předce jsou ten sjezd sobě o středopostí položený drželi a spolu se v nemalém počtu $\mathrm{v}$ Praze $\mathrm{v}$ koleji proti starobylému dobrému pořádku a obyčejům scházeli [...]. “ Instrukce Ferdinanda I. poslům do Prahy, 15. 5. 1547, Wittenberg. Sněmy české II, s. 261n; podobně také s. $293,309$. 
měšt’anů, kteří se v obavách před reakcí krále snažili zabránit Sixtovi z Ottersdorfu a dalším členům poselstva v odjezdu z Měst pražských do ležení u Wittenbergu. ${ }^{31}$ Poukazování na králem neschválené sjezdy v Karolinu se pak objevilo jako součást obvinění předáků stavovského tábora. ${ }^{32}$

Př́islušníci univerzity osobně bezprostředně postiženi nebyli, $\mathrm{k}$ jistým personálním změnám ale došlo - z pozice rektora po čtyřech měsících odstoupil a následně zcela opustil Prahu Jan Šentygar, známý svým př́mým a rozhodným vystupováním. Jeho polemika s Bohuslavem Hodějovským, synovcem známého mecenáše humanistických básníků a místosudího zemského soudu Jana Hodějovského z Hodějova, ukazuje Šentygarův ostrý nesouhlas s postupem Karla V. i Ferdinanda I. vičč říšským i českým stavům. ${ }^{33} \mathrm{Na}$ postu rektora ovšem nahradil Šentygara jeho prrítel Šebestián Aerichalcus, na univerzitě tak nedošlo k nějaké zásadní názorové diskontinuitě. ${ }^{34}$

V souvislosti s konfiskacemi byla univerzita ekonomicky postižena především v oblasti platů, které byly pojištěné na konfiskovaném městském majetku. Platy převzala česká komora, která je nevyplácela v plné výši. ${ }^{35}$ Konfiskace se týkala také vsi Sazená nedaleko Velvar, odkud byl zajišt'ován plat lektora řeckého jazyka, tedy M. Matouše Collina. Konfiskovaný statek se dostal do rukou prokurátora české komory Floriána Griespeka z Griespachu, ${ }^{36}$ který plat po několik let vyplácel, než byl v roce 1553 z rozhodnutí Ferdinanda I. plat lektora řečtiny pojištěn na komorní vsi Poříčany. Ta byla pak hned následujícího roku společně s celým panstvím Kostelec nad Černými lesy prodána Jaroslavu Smiřickému ze Smiřic, aniž by byl uvedený plat nově pojištěn. ${ }^{37}$ Matouš Collinus byl ovšem v té době mezi katolíky a staroutrakvisty persona non grata. $Z$ místa profesora řeckého jazyka byl králem odvolán $\mathrm{v}$ roce 1558.38

Podrobněji zatím nebyl prozkoumán dopad změn v podmínkách soudobého tisku na univerzitu, tedy na jedné straně zostřené cenzury, na druhé straně strmě stoupajícího počtu tiskařských privilegií udělovaných Ferdinandem I. po roce 1547. Např. v oblasti oblíbených kalendářu a minucí se rozmach konkurence nepochybně projevil. ${ }^{39}$

Porážka stavovského odboje znamenala rovněž znovuotevření otázky reformy univerzity, tentokrát ovšem z úplně jiných východisek, a to ze strany horní konsistoře a panovníka.

31 K. TieftrunK, Odpor staviov českých, s. 172-200.

32 Sněmy české II, s. 315, 335, 354, 368, 404, 415. Záznamy o dění roku 1547 z rektorských akt zpř́istupnili F. ŠMAHEL - G. Silagi (edd.), Statuta et acta, s. 107-110.

33 Josef Hejnic, Dva humanisté v roce 1547 (Rozpravy Československé akademie věd, řada společenských věd, roč. 67, seš. 7), Praha 1957, s. 26-35.

34 Záznam o Šentygarově volbě a rezignaci: MUP I/2, s. 343n.

35 Stručné dějiny University Karlovy, s. 87; M. Svatoš (ed.), Dějiny Univerzity Karlovy, I, s. 216. Př́íkladem může být ves Smolenice, konfiskovaná královskému městu Louny. M. HoLÁ, Studentské koleje, s. 190n.

36 Ke Griespekovu dobrému vztahu ke Collinovi a mecenátu přesahujícímu povinnosti držby vsi Sazená srov. Václav BưžEK, Ferdinand Tyrolský mezi Prahou a Innsbruckem. Šlechta z českých zemí na cestě ke dvorům prvních Habsburki̊, České Budějovice 2006, s. 103. Univerzita s ním přicházela do kontaktu i jako pozemková vrchnost, srov. záznam o dvou michelských venkovanech, kteří měli platit pokutu české komoře: MUP I/2, s. 347; F. ŠMAhel - G. Silagi (edd.), Statuta et acta, s. 110.

37 Zikmund WinTER, Děje vysokých škol pražských od secessi cizích národů po dobu bitvy bělohorské (14091622), Praha 1897, s. 55n; Michal Flegl, Florián Gryspek a Matouš Collin, Listy filologické 103, 1980 , s. 82-94; F. ŠMAHEL - G. SilaGi (edd.), Statuta et acta, s. 120n.

38 J. HeJnIC - J. MARTíneK, Rukovět', I, s. 419n.

39 Z. WINTER, O životě na vysokých školách pražských, s. 344; Karel BERÁNEK, Tiskařská privilegia České dvorské kanceláře v Státním ústředním archivu v Praze, Strahovská knihovna 12-13, 1977-1978, s. 75-77. 
Jednalo se o podobný plán, který byl uplatněn v př́padě vídeňské univerzity, při jistém zohlednění náboženských specifik českého prostředí (panovník nabídl platit profesory bez rozdílu vyznání, pokud bude mít právo jmenovat je). Míra zásahů do autonomie školy byla pro mistry kolegiáty i pro nekatolické stavy nepřijatelná, proto z reformy záhy sešlo. ${ }^{40} \mathrm{Králi}$ se tak otevřel prostor pro řešení v podobě povolání jezuitů.

V 50. a 60. letech 16 . století procházela změnami tradiční vazba univerzity $\mathrm{k}$ dolní (utrakvistické) konsistoři sídlící př́mo v Karolinu. Výslovně konfliktní byl vztah s administrátorem M. Janem Mystopolem, zvláště poté, co univerzita zaujala negativní postoj k plánům na sblížení staroutrakvistů s katolíky na konci 40. let. Otevřený spor vyvolalo dosazení Mystopola jako kazatele do Betlémské kaple a koleje Všech Svatých, kterou se pokusil odtrhnout od univerzity. Postupně klesal také počet mistrů kolegiátů mezi konsistoriány. ${ }^{41}$

Otázkou, jíž byla v souvislosti s dějinami pražské univerzity za panování Ferdinanda I. nedávno věnována samostatná pozornost, je podoba sítě městských škol v této době. ${ }^{42}$ Oproti přelomu 16. a 17. století, kdy je soudobá situace poměrně detailně známa, existuje pro sledované období řada dílčích bílých míst - je zrejmé, že se vedle zavedených škol ve velkých městech v řadě lokalit teprve konstituovaly samostatné instituce pro základní, prípadně střední stupeň vzdělání. Univerzita si nárokovala dohled nad nižším školstvím již v době jagellonské, nebylo tomu jinak ani v následujících desetiletích. Ve vztahu k městům pražským představuje důležitý moment jednání s radami Starého a Nového Města započaté roku 1533, vedoucí k omezení soukromých škol a upevnění dohledu rektora univerzity nad pražským partikulárním školstvím. ${ }^{43}$ Pokud jsme tu ovšem zmiňovali její částečně problematickou situaci v období po r. 1547, patř́ k jejím symptomům také privilegium Ferdinanda I. pro litoměřickou městskou školu (1549), které je jasným narušením všeobecně nárokovaného dohledu ze strany pražské univerzity: „Také tomu chceme [...], aby nynějš́ i budouci Mistři neb praeceptorové v té škole litoměřické vši té svobody a práva uživali a bez překážky rektora i Mistruov pražských uživati mohli, jako jiní v takových a k té podobných obzvláštnich školách uživaji [...]“. ${ }^{44}$ Součástí ustanovení byl také požadavek na osobu vyučujícího, jejž dosazovala městská rada a měl jím být mistr svobodných umění výhradně katolického nebo utrakvistického vyznání. Praxe ale byla nakonec silnější - mezi předbělohorskými rektory této školy byli mladí muži různého vyznání (včetně luteránů a českých bratrů), a to takřka výhradně z řad absolventů pražské univerzity, 45

40 Z. Winter, Děje, s. 40n; Stručné dějiny University Karlovy, s. 86; Jaroslav PÁnek, Stavovská opozice a jeji zápas s Habsburky 1547-1577, Praha 1982, s. 32; Klement BorovÝ (ed.), Jednání a dopisy konsistoře katolické i utrakvistické, II, Praha 1869, s. 62n. Z předcházejících konfesijně orientovaných sporů o městské školy v českých zemích zmiňme alespoň případ Kadaně z konce 30. let 16. století, tam ale pražská univerzita nejspíše nehrála žádnou roli. Srov. Sněmy české I, Praha 1874, s. 423-426.

41 MUP I/2, s. 353n; F. Šmahel - G. Silagi (edd.), Statuta et acta, s. 115; Z. Winter, Děje, s. 40n; Stručné dějiny University Karlovy, s. 87.

42 Marek DuURČAnSKÝ, Pražská utrakvistická univerzita a česká města za vlády Ferdinanda I., s. 162-167.

43 F. ŠMAHEL - G. Silagi (edd.), Statuta et acta, s. 86-89.

44 Oldřich Kotyza - Jan Smetana - Jindřich Smetana et al., Dějiny města Litoměřic, Litoměřice 1997, s. 179n., 367 (zakládací listina školy, přetištěno dle František DvorskÝ (ed.), Paměti o školách českých. Listár školství českého v Čechách a na Moravě od l. 1598 do 1616 s doklady starši i pozdějši doby, Praha 1886, s. 49-50). V kontextu srov. též Zikmund WINTER, Život a učeni na partikulárních školách v Čechách v XV. a XVI. století, Praha 1901, s. 164n. Tehdejší rektor pražské univerzity Jan Hortensius (Zahrádka) si o záležitosti rovněž neopomněl učinit záznam do rektorských akt. F. ŠmaHeL - G. SilaGi (edd.), Statuta et acta, s. 112n.

45 Julius Lippert, Geschichte der Stadt Leitmeritz, II, Prag 1871, s. 462-464. 
počítaje v to i osobnosti formátu M. Pavla Stránského ze Zapské Stránky. ${ }^{46}$ Hned v roce 1550 se ostatně stal jejím rektorem M. Adam Vodička (Aquila) Žatecký, absolvent z Vitenberka, přijatý o čtyři roky dříve mezi profesory pražské univerzity. Jeho odchod do Litoměřic byl zaznamenán také v Liber decanorum a v rektorských aktech. ${ }^{47}$ Jeví se mi jako nemyslitelné, že by na výběr př́íslušného člena akademické obce nakonec neměl vliv rector magnificus. Lze tedy soudit, že systém městského partikulárního školství napojený na pražskou univerzitu byl v polovině 16 . století již natolik zaběhlý a funkční, že jej dílčí narušení - byt' v jedné z významných lokalit - nemohlo ohrozit, naopak se ukázalo jako dlouhodobě neudržitelné.

Jeden z běžných aspektů ve vztahu univerzity k pražským městům, především Starému Městu pražskému, představovala prostá fyzická prrítomnost univerzity ve městě a z ní vyplývající konfliktní pole vzájemného každodenního soužití, at’ už se jednalo o mezilidské vztahy nebo stavebně-technické otázky. Mohlo se jednat o drobnější problémy, jako byl chlév pro vepře jistého Pavla, řečeného Žák (resp. Paulus Pistor), obtěžující obyvatele koleje mediků na počátku 40. let, ${ }^{48}$ ale také zásadnější záležitosti ovlivňující fungování ústředních míst akademického života. Ty byly na pořadu dne v průběhu 50 . let 16 . století v př́ipadě Karolina opakovaně, přičemž do jejich řešení vedle městských úradů vstupoval také panovník, resp. jeho zástupci. V roce 1551 vznesl probošt a mistři Karlovy koleje na arciknížete Ferdinanda stížnost týkající se odpadní strouhy v okolí Karolina. Z rozhodnutí arciknížete a za prostřednictví komisařů, v čele s purkmistrem Starého Města pražského, byla uzavřena smlouva mezi mistry kolegiáty Karlovy koleje a radou Starého Města „o tok vody“. Obsahovala ustanovení o likvidaci zmíněné smrduté strouhy, která vedla prímo podél koleje a do níž byla sváděna voda ze střech většiny domů v Úzké ulici, ${ }^{49}$ ale patrně nebyly výjimkou ani jiné tekutiny a odpad. Mistři souhlasili se svedením této stoky do zahrady Karolina, ovšem ,tímto spi̊sobem: maji udělané bejti veliké trouby požerací pod zemí, tak aby $v$ zahradě smradem ani jinak škoda nedála se“, a to s př́íslušnými „špunty“ pro pravidelné čištění, obojí na náklad staroměstské obce. ${ }^{50}$

V roce 1558 mistři znění této smlouvy na vyžádání parafrázovali v listu maršálkovi Království českého. ${ }^{51}$ Dokument patrně souvisel se soudobou sérí jednání, v nichž se představitelé pražské univerzity obraceli na císaře Ferdinanda I., arciknížete Ferdinanda Tyrolského, českou komoru, ale také na české stavy. Žádali o odpuštění berně z univerzitních vesnic s poukazem na mimořádně špatný stav Karolina, zejména dezolátní stav krovů, kvůli němuž do budovy na mnoha místech zatékalo. Na stavy apelovali s poukazem na důležitost

46 V tomto kontextu není důležité, zda byl Pavel Stránský českobratrské konfese nebo ne. Pro jeho novoutrakvistické vyznání přesvědčivě František MAREK, Pavel Stránský, Ústí nad Labem 1983, s. 21-25.

47 MUP I/2, s. 351n; F. Šmahel - G. Silagi (edd.), Statuta et acta, s. 113; Josef HejniC - Jan MartíneK, Rukovět' humanistického básnictvív Čechách a na Moravě, V, Praha 1982, s. 519n.

48 Vzniklý spor byl řešen šestipanským úřadem Starého Města pražského. MUP I/2, s. 324n; F. ŠMAHEL - G. Silagi (edd.), Statuta et acta, s. 93n.

$49 \mathrm{~K}$ dějinám některých domů uvedených ve smlouvě srov. Jiří ČAREK, Z dějin staroměstských domů. [Ovocný trh a Haviřská ulice. Nároži Staroměstského náměstí a Celetné ulice], Pražský sborník historický 19, 1986, s. 5-34.

50 AUK, sign. A 47, fol. 49r-50v; Z. WINTER, O životě na vysokých školách, s. 55n. Winter cituje rukopis z Archivu města Prahy, č. 324, fol. 171, bohužel se nejspíše jedná o jeden ze svazků souboru pamětihodných zápisů, tzv. Chaos rerum memorabilium, který shořel při požáru Staroměstské radnice v r. 1945. Srov. Jiří ČAREK a kol., Městské a jiné úředni knihy Archivu hlavniho města Prahy (Přehled), Praha 1956, s. 44.

51 AUK, fond Rukopisy A, sign. A 47, fol. 29r-v. 
největši univerzitní koleje: ,aby takové ušlechtilé, nákladné a starodávni staveni, kteréž jest J. M. C. a Vašich [Milos] tí i všeho Království českého potřebný a užitečný klenot a poklad, $k$ dalšimu spuštěni, boření a snad i k skáze nenapravitedlné (čehož P. Bůh rač uchovati) nepřišlo“. V odůvodnění své finanční tísně uváděli, že se sami už museli kvůli nezbytným opravám zadlužit a dále, že ,naděje není, aby někdo na ten čas, jakž se predešle, ač i tehdáž zř̉idka trefovalo, skutek milosrdný učiniti a na opravu téhož domu odkázati chtěl". Císař prostřednictvím svého syna s návrhem souhlasil. Ferdinand Tyrolský poté pověřil v červnu 1559 hejtmany Starého a Nového Města pražského, aby společně s „,paumeistrem“ Pražského hradu situaci na místě prohlédli a navrhli řešení. ${ }^{52}$

V té době již měla utrakvistická univerzita konkurenci v jezuitském Klementinu, vydatně podporovaném rovněž nezanedbatelnou částí vyšších stavů. ${ }^{53}$ Vzájemné soupeření mělo řadu podob. Jednou z nejviditelnějších byly školní divadelní hry a účast na slavnostech. Divadelní hry připravené mistry a žáky utrakvistické akademie zajištovaly př́stup k panovníkovi, pobývajícímu před rokem 1547 v Praze mnohem častěji, již ve 40 . letech, např. hra Susanna předvedená v r. 1543 na Pražském hradě. Za provedením stál Šebestián Aerichalcus, na jehož zásluhy na poli dramatického umění se dlouho vzpomínalo.$^{54}$ Jezuité byli velmi dobře viditelní při slavnostních vjezdech Ferdinanda I. roku 1558 a arciknížete Maxmiliána roku 1562 - výzdobou v okolí Klementina i symbolickými výstupy během vítání obou Habsburků. V prvním př́padě měl mít způsob, jakým o slavnosti pojednal ve svém popisu Matouš Collinus, přímý důsledek v císařově nemilosti. ${ }^{55}$ Pro intelektuální milieu pražské univerzity 50. let je důležité propojení humanistického okruhu Jana st. Hodějovského z Hodějova s městským, ale zároveň také dvorským prostředím; ${ }^{56} \mathrm{v}$ politické rovině se ovšem městskému stavu vzdaluje a přibližuje naopak nekatolické šlechtě.

V posledních letech panování Ferdinanda I. vstoupil do poměrů určujících postavení pražské univerzity ještě jeden faktor - obnovené pražské arcibiskupství a jeho první představitel Antonín Brus z Mohelnice. ${ }^{57}$ Podle původních privilegií a statut byl arcibiskup zároveň kancléřem univerzity. Přestože se Brus myšlenkami na katolickou reformu univerzity zabýval a předložil je také počátkem roku 1562 Ferdinandovi I., soudobá situace nedávala arcibiskupovi argumentujícímu tím, že stará univerzitní privilegia byla vydána katolickou vrchností pro katolíky, př́liš šancí na úspěch. Sám Ferdinand I. s velkou pravděpodobností již tehdy vkládal hlavní naděje do jezuitů (jeho odpověd' na Brusovo memorandum se patrně nedochovala, byla-li napsána). ${ }^{58}$ Jak citlivou se ale mohla otázka

52 Tamtéž, fol. 29v-33v, citáty na fol. 30v-31r; Z. WinTER, Děje, s. 56.

53 Přehledně Dějiny Univerzity Karlovy, I, s. 247-268. Srov. také lakonický záznam v Liber decanorum: MUP I/2, s. 361, podobně F. ŠMAHEL - G. Silagi (edd.), Statuta et acta, s. $121 \mathrm{n}$.

54 Z. WinTer, O životě na vysokých školách, s. 440n.; J. HeJNIC - J. MarTíneK, Rukovět', I, s. 50. Je výmluvné, že samostatný zápis je obsažen také v Liber decanorum. MUP I/2, s. 329n.

55 Z. Winter, Děje, s. 53n., 56; stř́zlivěji J. Hausenblasová, Ferdinand I. a pražský humanistický okruh, s. 95n.

56 Lucie Storchová, Paupertate styloque connecti. Utvárení humanistické učenecké komunity v českých zemích, Praha 2011, s. 156-182. Srov. také záznam o jeho pokusu z roku 1550 o zř́zení nové profesury s ročním platem 16 kop míšeňských, zaměřené na čtení duchovních básníků. F. ŠMAHEL - G. SilaGi (edd.), Statuta et acta, s. 113n.; Z. WinTER, Děje vysokých škol pražskích, s. 56n.

57 Také nástup Antonína Bruse z Mohelnice na pražský arcibiskupský stolec v roce 1561 „,de voluntate caesaris Ferdinandi cum consensu summi pontificis“" byl tehdejším děkanem filozofické fakulty M. Pavlem Kristiánem z Koldína do úřední knihy zaznamenán. MUP I/2, s. 373, podobně také do rektorských akt: F. ŠMAHEL - G. SilaGi (edd.), Statuta et acta, s. 129.

58 Anna SкÝBOvÁ, Obnovení pražského arcibiskupství v letech 1561-1562 a jeho vztah k pražské univerzitě, AUC-HUCP 7, 1966, s. 62-72; František KAVKA - Anna SкÝBOvÁ, Husitský epilog na koncilu tridentském 
arcibiskupova kancléřství za jiných poměrů stát, dokládají pozdější spory kardinála Arnošta Vojtěcha z Harrachu s jezuity.

S Ferdinandem I. se univerzita rozloučila během jeho pražského pohřbu, kdy arcikníže Ferdinand nařídil, jaký mají mít profesoři a další př́slušníci univerzity oděv a kde bude jejich místo $\mathrm{v}$ rámci pohřebního průvodu v blízkosti pražských radních a představitelů ostatních měst. ${ }^{59}$

Na závěr lze shrnout, že vazba univerzity na města $\mathrm{v} 60$. letech už měla poněkud jinou podobu, než na začátku 20. let, včetně vztahu $\mathrm{k}$ městům pražským, který už zdaleka nebyl tak dominantní. Zájem panovníka o univerzitu opadl po stavovském odboji roku 1547, který měl negativní vliv i na její materiální zajištění. Královská města, k nimž měla v první polovině 16. století pražská univerzita nejužší vazby, byla za účast v odboji potrestána nejvíce, ve srovnání s vyššími stavy neúměrně svému provinění. Reálné postihy ovšem ani náznakem nedosáhly důsledků stavovského odboje let 1618-1620. Tehdy se i Jan Campanus v jedné básni dovolával mírnosti, s níž postupoval Ferdinand I. ${ }^{60}$

\section{MAREK ĎURČANSKÝ}

\section{Die Prager Universität unter Ferdinand I. - ihre Beziehung zum Herrscher und zu den Prager Städten}

\section{ZUSAMMENFASSUNG}

Der Beitrag untersucht parallel die Beziehung der Prager Utraquisten-Universität zum Prager Städteverband und zum böhmischen Herrscher unter dem Habsburger Ferdinand I. (1526-1564). Der Einfluss der Universität war damals vorwiegend auf das Binnengebiet Böhmens selbst beschränkt. In dem Machtkampf zwischen den Adelsständen und dem städtischen Stand stand sie den Städten, insbesondere Prag näher. Das änderte sich selbst dann nicht, als sich infolge der Reformation, der königlichen Fiskalpolitik und anderer Umstände eine Ständeopposition herausbildete, der der größte Teil des städtischen Standes angehörte. Die Politik Ferdinands I. aber war offen gegen die Städte gerichtet, was sich insbesondere während des Ständewiderstandes 1547 und in den Sanktionen nach seinem Abklingen zeigte. Die Bindung an die böhmischen Städte vermochte die Universität zwar immer weniger politisch zu nutzen, doch blieb diese Bindung in der Frage des normalen Universitätsbetriebes auch weiterhin von Bedeutung (die meisten Scholaren stammten aus städtischem Milieu und die Universität kontrollierte die personelle Besetzung der städtischen Schulen). In diese Bindungen einzugreifen, versuchte der Herrscher nach 1547, indem er beispielsweise in Leitmeritz eine universitätsunabhängige Schule gründete, doch erwies sich das bisherige Netz städtischer Schulen auch weiterhin als ein starkes, funktionstüchtiges System.

Die Beziehung der Prager Hohen Schule zu Ferdinand I. war von behutsamer, keineswegs aber von offen negativer Natur. Zahlreiche Professoren hatten bindende Beziehungen zum höfischen Milieu, die Universität nahm an offiziellen, mit dem Herrscher verbundenen Feierlichkeiten teil, und in den Ansätzen zu einer Reform der Hochschule zeigten sich potenzielle Inspirationen durch die kurz vorher erfolgte Reform der Wiener Universität (größere Abhängigkeit vom König im Tausch gegen finanzielle Absicherung). Nach dem Scheitern dieser Ansätze war der Weg frei, um die Jesuiten nach Prag zu holen, die hier ein katholisches Gegengewicht zu der nichtkatholischen Universität schaffen sollten.

a pưvodní koncepce habsburské rekatolizace Čech. Počátky obnoveného pražského arcibiskupství, Praha 1969, s. 166-169. Autoři upozorňují, že stejnou argumentaci užíval během svého sporu s univerzitou v roce $1561 \mathrm{M}$. Havel Gelastus Vodňanský. Srov. K. Borový (ed.), Jednání a dopisy konsistoře katolické i utrakvistické, I, s. 379 n.

59 F. Šmahel - G. Silagi (edd.), Statuta et acta, s. $131 \mathrm{n}$.

60 Z. WINTER, Děje vysokých škol pražských, s. 178. 
Die Beziehung zu den Prager Städten wird neben den politischen Bindungen auch auf dem Gebiet des alltäglichen Zusammenlebens untersucht, welches beispielsweise Konflikte zwischen der akademischen und der städtischen Jurisdiktion, Reparaturen an den Universitätsgebäuden oder Probleme der Kirchenverwaltung umfasst.

Die Bindungen der Universität an die Stadt hatte in den 1560er Jahren bereits einen anderen Charakter als zu Beginn der 1520er Jahre, die Beziehung zu den Prager Städten inbegriffen, obwohl sie längst nicht mehr so dominant war. Seitens des Herrschers gab es vor dem Ständewiderstand eine gewisse Hoffnung (die real aber nur gering war), dass die Universität eine landesherrliche Einrichtung werden könnte. Doch kam dies nach dem missglückten Ständewiderstand prinzipiell nicht in Frage.

Deutsche Übersetzung Wolf B. Oerter

Marek Ďurčanský

Ústav dějin a archiv Univerzity Karlovy, Praha

marek.durcansky@ruk.cuni.cz 